\title{
Contagion Phenomena in Financial Crises: Evidence from the Portuguese and Spanish Exchange Rate Crises in the Early 1990s*
}

\author{
Margarida Abreu \\ Instituto Superior de Economia e Gestão - CISEP.
}

\begin{abstract}
Based on the experience of the Portuguese and Spanish financial crises in the early 1990s, this paper suggests that the spillover of exchange rate crises may reveal a particular dimension of the financial contagion effect: the presumption of mimetic behaviour by monetary authorities.

This paper analyses the evolution of the credibility of the Escudo and the Peseta. We set out to test the existence of a contagion effect: that is, in what way does the polarization of exchange rate expectations in a scenario of devaluation of one currency explain the building up of a similar scenario for the other currency? We also examine the transmission mechanisms of such a scenario.

Our results suggest the existence of a one-way contagion effect, of the Escudo by the Peseta. Speculative attacks against the Peseta necessarily give rise to speculative attacks against the Escudo, regardless of the evolution of the 'fundamentals' of the Escudo. In this case, the spillover

\footnotetext{
*I'm grateful to two anonymous referees and to V. Mendes for valuable comments on an earlier version of this paper. The usual disclaimer applies.
} 
of financial crises could be better understood by the anticipated mimetic behaviour of monetary authorities, rather than by the geographical proximity of the countries in question or by the identical performance of the economies of both.

\section{Introduction}

The Spanish Peseta joined the EMS exchange rate mechanism (ERM) in August 1989 and the Portuguese Escudo followed suit in April 1992. Both currencies participated in the $\pm 6 \%$ fluctuation band around the central parity until the widening of the band in August 1993. From the very beginning and until the general EMS crisis in September 1992, the external nominal value of both currencies remained stable. Both the Peseta and the Escudo were among the strongest currencies in the mechanism: they remained well within the superior half of their fluctuation band, appreciated relative to their central parities as well as to the Deutschmark. Despite this past behaviour, both currencies were subject to numerous speculative attacks, far beyond the general EMS crisis, giving rise to three simultaneous currency devaluations of the respective central parities between September 1992 and March 1995.

Prior research ${ }^{1}$ has attempted to find possible reasons for the Portuguese and Spanish exchange rate crises of the early 1990s. However, to the best of our knowledge, none of these studies looked for contagion arising from links between events in the two countries.

There are several explanations as to why crises tend to be bunched or clustered (Caramazza et al. 2000; Jeanne 1999; Williamson 2000b). A crisis in one country can spread to others via trade links. Once one country has devalued, it is costly (in terms of a loss of competitiveness and output) for other countries, who have strong trade links with the first country to maintain their parities (Glick and Rose 1999). An original disturbance can also spread across countries via financial links. Abreu and Scialom (2000) and Calvo (1996) stress the role of liquidity. A leveraged investor facing margin calls needs to sell his asset holdings. This leads to other asset prices being depressed. Goldstein et al. (2000) highlight the role of common lenders: the need to rebalance the overall risk of a bank's asset portfolio can lead to a credit crunch. Another family of contagion models has emphasized the role of the correlation of fundamentals in the presence of asymmetric information among investors (Kodres and Pritsker 1998).

\footnotetext{
${ }^{1}$ See for instance Bartolini and Prati (1999), Campa and Chang (1998), Kempa and Nelles (1999), Peria (1999), Favero and Giavazzi (2000) or Gómez-Puig and Montalvo (1997).
} 
The Portuguese and Spanish exchange rate events studied in this paper seem to correspond to another special case of contagion. In this case, spillover seems to be better explained by the anticipated mimetic behaviour of the Portuguese monetary authorities vis à vis the Spanish monetary authorities, rather than focusing on the geographical proximity of the countries or on the strong direct trade or financial links existing between them. We view this phenomenon as a particular case of the escape clause approach to currency crisis (Eichengreen and Wyplosz 1993; Isard 1995; Sutherland 1995).

The escape clause approach views exchange rate arrangements as conditional commitment devices. A country which adheres to a fixed exchanged rate arrangement commits itself to maintain the exchange rate within a particular band, in view of certain benefits. This commitment is, however, limited, in the sense that the country's policy maker may always have recourse to the escape clause, i.e., if the costs associated with the fixed peg come to outweigh the benefits of the same. From this perspective, a currency crisis is a situation in which private agents perceive that monetary authorities are on the brink of abandoning the prevailing exchange rate policy.

What would seem to be particular to the Portuguese case is that market expectations of the monetary authorities' evaluation of benefits and costs depend mostly on the likelihood of Spanish monetary authorities abandoning the prevailing exchange rate commitment in response to a speculative attack. If Spanish authorities respond to an attack with a devaluation of the Peseta, this will sharply increase the cost of the prevailing exchange rate policy in Portugal. Investors revise their beliefs on the continuity of the Portuguese commitment to the exchange rate system insofar as mimetic behaviour of Portuguese monetary authorities is expected. Speculative attacks against the Peseta necessarily lead to speculative attacks against the Escudo, regardless of the evolution of the 'fundamentals' of the Escudo.

We evaluate this contagion effect via the econometric estimation of the expected rate of depreciation of each currency in the band, using information pertaining to the other country's financial market as explanatory variables.

Considering that among European ERM members, interest rates were, during this period, almost the only effective monetary instrument, we used the influence of interest rates on the expected rate of depreciation of the Escudo within the band as a proxy for the effect of monetary policy on exchange rate expectations. ${ }^{2}$

\footnotetext{
${ }^{2}$ Figure 1 shows exchange rates of the Portuguese Escudo and the Spanish Peseta against the Deutschmark and the one-month Portuguese and Spanish interest rates.
} 


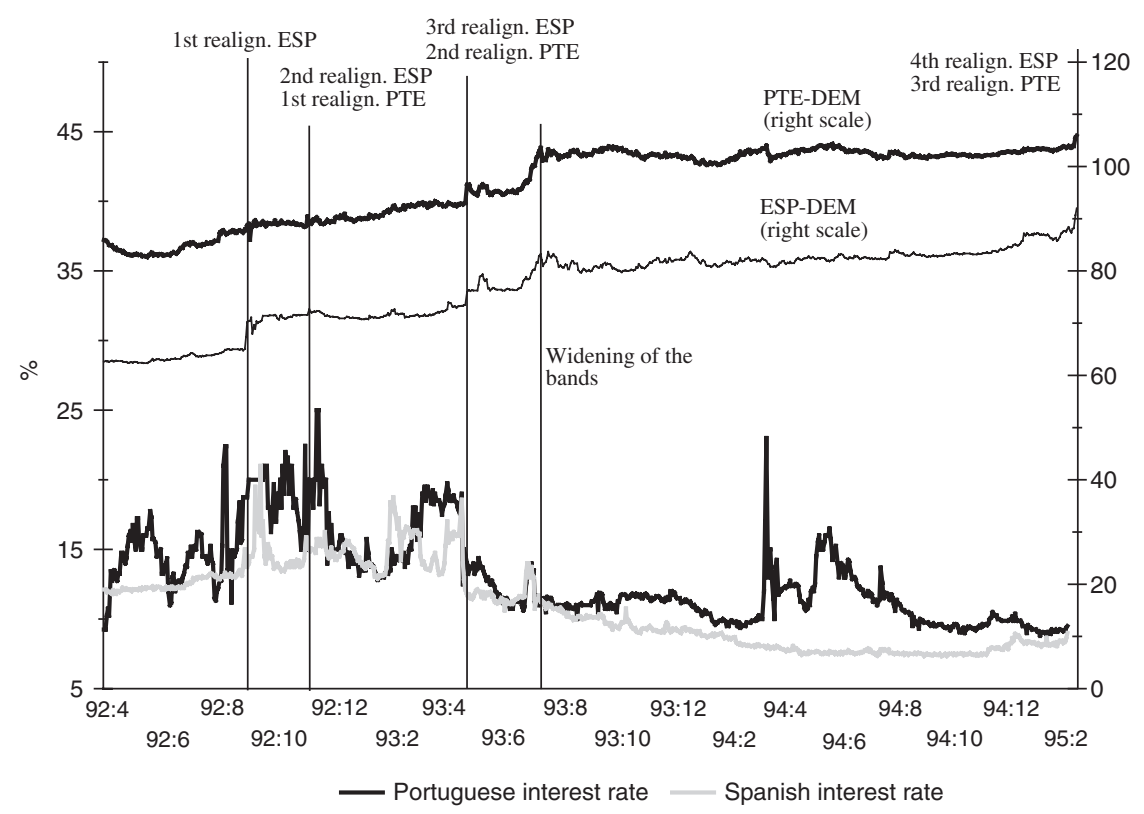

Figure 1: Exchange rates against DEM 1 month interest rates

Section II briefly presents the parametric tests used to evaluate the credibility of the exchange rate policy in each country. Section III presents our own estimations: the expectation of a currency devaluation is measured here by the interest rate differential, adjusted by the estimated depreciation expectation of a currency within the band. Conclusions are presented in Section IV. Our results suggest the existence of a one-way contagion effect, of the Peseta on the Escudo. The Peseta does not suffer any impact as a result of fluctuations in the credibility of the Escudo exchange rate. In this case, the spillover of financial crises can be better understood by the anticipated mimetic behaviour of monetary authorities rather than by the geographical proximity of the countries or by an identical performance of the economies of both countries.

\section{Parametric Credibility Tests}

We estimated the anticipated rate of devaluation for the Escudo and for the Peseta using parametric credibility tests in the tradition of Svensson (1991a), Rose and Svensson (1991) and Bertola and Caballero (1990). It was assumed that the anticipated total rate of depreciation of a currency is equal to the interest rate differential, i.e. we accept the hypothesis of uncovered interest rate parity. In this case, the anticipated devaluation rate in a fluctuation 
band regime equals the difference between the interest rate differential and the currency's depreciation within the band. This is a parametric method in the sense that the anticipated depreciation rate within the band is estimated rather than computed from the full width of the fluctuation band (as in the simple credibility tests - Svensson 1991b).

The expected devaluation rate can therefore be defined as follows:

$$
g_{t}^{m}=\delta_{t}^{m}-E_{t}\left[\left.\Delta x_{t+m}\right|_{\text {no realignment }}\right] / m \cdot d t
$$

where:

$g_{t}^{m}$ is the expected rate of devaluation (at period $t$ ) of the central parity $m$ periods in advance (if it is positive a devaluation is expected); this is equal to the difference between the interest rate differential and the expected rate of depreciation within the band;

$\delta_{t}^{m}=i_{t}^{m}-i_{t}^{* m}$ is the interest rate differential (domestic rate - foreign rate) at period $t$, on bonds with maturity $m$;

$x_{t}=s_{t}-c_{t}$ is the difference between the log of the market exchange rate $s$ and the log of the bilateral central parity $c$;

$m$ is the maturity measured in periods and $d t$ is the length of the period;

$E_{t}\left[\left.\Delta x_{t+m}\right|_{\text {no realignment }}\right] / m . d t$ is the expected (at period $t$ ) depreciation rate within the band, between periods $t$ and $(t+m)$, conditional upon the non-existence of a realignment and $\Delta x_{t+m}=x_{t+m}-x_{t}$.

The expected devaluation rate of the domestic currency (Escudo for Portugal and Peseta for Spain) in relation to the Deutschmark within a certain time horizon was calculated as the expected domestic rate of depreciation of the currency within the band, subtracted from the interest rate differential between each of the Iberian countries and Germany. The expected depreciation within the band was estimated by OLS using the following equation:

$$
\left(x_{t+m}-x_{t}\right) / m \cdot d t=\sum_{j} \beta_{0 j} d_{j}+\beta_{1} x_{t}+\beta_{2} \Delta_{p t e}^{m}+\beta_{3} \Delta_{e s p}^{m}+\varepsilon_{t+m}
$$

where:

$d_{j}$ : dummy variables, identifying each time period between two realignments. We therefore allow for (and are able to test) different anticipated depreciation rates between realignments. If a coefficient is positive and significant, this means that, on average, the Escudo (Peseta) was a weak currency within the band during the period between the two realignments;

$x_{t}$ : as above, is the exchange rate within the band, and is frequently used as the sole explanatory variable when explaining $\Delta x_{t+m}$. The coefficient of $x_{t}$, if negative and statistically significant, shows the existence of a force 
pulling the exchange rate towards the central parity, i.e. the deviation of the exchange rate has a stabilizing effect;

$\Delta^{m}{ }_{p t e}$ and $\Delta^{m}{ }_{e s p}$ represent the difference between the euro interest rates in Portugal and Germany $\left(\Delta^{m}{ }_{p t e}\right)$ and in Spain and Germany $\left(\Delta^{m}{ }_{e s p}\right)$. The use of $\Delta^{m}{ }_{\text {esp }}$ allows us to test the influence of the stability of the Peseta market on the Escudo market.

We wished to estimate the expected depreciation rate within the band, conditional upon information available at time $t$ for one, three and twelvemonth horizons. Therefore, we consider m.dt equal to $1 / 12$ year, $1 / 4$ year and 1 year, respectively (this corresponds to $m$ equal to 21, 64 and 254 daily observations and $d t$ equal to $1 / 254$ ). As we wished to calculate the expected depreciation rate within the band conditional upon no realignment between dates $t$ and $t+m$, therefore, for the 1-month horizon, we excluded from the sample the last 21 observations prior to each realignment. For the same reasons, we excluded from the sample 64 (254) observations prior to each realignment so as to estimate the expected depreciation rate within the band in the 3-month (12-month) horizon.

Exchange rate depreciation expectations were estimated by OLS. However, we computed standard errors using a Newey-West covariance estimator, allowing for both serial correlation and heteroscedasticity, since the dates overlap.

\section{Data and Results}

\section{A. Data}

The credibility of the Escudo exchange rate band in the EMS was empirically checked through the use of data covering the period from 14 April 1992, one week before the Escudo joined the European exchange rate mechanism, to 5 March 1995. During this period, the central parity of the Escudo against the Deutschmark was changed 3 times (involving three devaluations against the Deutschmark): on 23 November $1992(-6 \%), 14$ May $1993(-6.5 \%)$ and 6 March 1995 (-3.5\%), which was practically the closing date of the series available to us.

Since the Spanish Peseta joined the exchange rate mechanism before the Escudo, we considered two series for this currency. One is longer and covers the whole period of the Peseta's participation in the ERM from 19 June 1989 to 5 March 1995; the other is shorter and is identical to that of the Escudo, in order to facilitate comparisons. During this period, the central parity of the Peseta against the Deutschmark was devalued 4 times: on 17 September 1992 (-5\%), 23 November 1992 (-6\%), 14 May 1993 (-8\%) and 6 March 1995 $(-7 \%)$. 
The credibility tests were carried out using the official central parities of these currencies in relation to the Deutschmark as the standard reference. Our choice presupposed the recognition of the role of the Deutschmark as an anchor for the system. We used ECU spot exchange rates, which were recorded daily at a mid-morning central bank telephone conference. ${ }^{3}$ We therefore deduced the exchange rates of the Portuguese Escudo and the Peseta in relation to the Deutschmark. These exchange rates were compared with the official central parities of these currencies vis-à-vis the Deutschmark, and with a variation range of $\pm 6 \%$, in spite of the widening of the official margins agreed to on 2 August 1993. Such a choice was justified by the fact that, after this date, the Escudo was kept within an implicit band, which corresponded to the earlier band of 12\% (Abreu 1999a). As far as the Peseta was concerned, a similar phenomenon was to be noted until December 1994 (Cassola 1995; Dolado et al. 1992). After the crisis that occurred in the summer of 1993, the DEM-ESP exchange rate also seems to have been kept within an implicit band, corresponding to the ranges of variation authorized before the widening of the bands. However, from the beginning of December 1994 until the last realignment in March 1995, this exchange rate policy seems to have been abandoned, with the DEM-ESP parity exceeding the ceiling of 84 Pesetas per Deutschmark ${ }^{4}$ on a continuous basis, despite the general increase in interest rates on the europeseta.

We used daily Portuguese, Spanish and Germany interest rates, for the period from 14 April 1992 to 5 March 1995. The interest rates used are annualized bid rates for 1-month, 3-month and 12-month euro-market deposits, recorded at 10 a.m. Swiss time.

\section{B. Estimations of the Expected Rates of Depreciation Within the Band $^{5}$}

The influence of monetary policy on expectations as regards the rate of depreciation of the Escudo

The assessment of the influence of interest rates on the expected rate of depreciation of the Escudo within the band can be considered as being a proxy for the effect of monetary policy on exchange rate expectations

\footnotetext{
${ }^{3}$ In comparison with the 'official fixing' dollar rates, the ecu-rates have the advantage of being simultaneously recorded for the relevant currencies.

${ }^{4}$ The ceiling corresponds to the band of variation of $\pm 6 \%$.

${ }^{5}$ We use LIMDEP in our calculations.
} 
(Svensson 1990; Moutot and Namur 1991). ${ }^{6}$ An effective Portuguese interest rate policy will be revealed by a positive $\beta_{2}$ coefficient. Likewise, the influence of Spanish monetary policy on the behaviour of the Portuguese exchange rate within the band will be revealed by a significant $\beta_{3}$ coefficient.

As far as the influence of interest rate differentials on the expected rate of depreciation of the Escudo is concerned, results in Table 1 seem rather disappointing. In fact, $\beta_{2}$ and $\beta_{3}$ are not significant for the one- and threemonth regressions, and only $\beta_{3}$ is significant as regards the one-year regression. For such a maturity, $\beta_{3}$ is, in fact, both negative and statistically significant, while the Escudo-Deutschmark interest differential is negligible. The Peseta interest rate therefore seems to play a decisive guiding role, while the influence of the Escudo interest rate on the formation of expectations about the depreciation of the Escudo would seem to be negligible, both for this time period and for the 1- and 3-month horizons. The fact that $\beta_{3}$ is negative suggests that an increase in the interest rate differential between the Peseta and the Deutschmark led to a reduction of the depreciation rate of the Escudo within the band. To put it more simply, an increase in Spanish rates (given German rates) reinforced the Escudo.

How can we interpret this set of results? Two possible explanations can be given:

1 Portuguese authorities were following the behaviour of their Spanish counterparts, who were pursuing an effective policy in terms of the exchange rate objective. While the rise in interest rates in Spain strengthened the Peseta (and this is confirmed by the negative sign of the coefficient $\beta_{3}$ estimated for the expected rate of depreciation of the Peseta - Table 2), it also provoked an immediate increase in Portuguese interest rates, since the Portuguese authorities knew that otherwise their currency would be subject to an attack. Thus, an increase in Spanish interest rates would have the effect of restoring the equilibrium of the Escudo exchange rate within the band. An analysis of the correlation between the two series of interest rates, as well as a study of the possible relations of causality between the variations in

\footnotetext{
${ }^{6}$ In truth, it is not in fact monetary policy that is at stake here, but rather certain variables which are directly influenced by this policy and the precise effects on which we do not know. The use of the euromarket interest rates is not disapproved whenever we assume, as we do in this paper, that the monetary link takes place through interest rates. In fact, after the complete liberalization of capital movements in December 1992, domestic and euromarket interest rates do not differ significantly.
} 
Table 1: Exchange Rate Depreciation within the Band with Interest Rate Differentials as Independent Variables ${ }^{\dagger}$

DEM-PTE

\begin{tabular}{lccc}
\hline & 1 month & 3 months & 1 year \\
\hline $\mathrm{d}_{1}: 14 / 04 / 92$ to $22 / 11 / 92$ & 0.042 & 1.916 & \\
$\mathrm{~d}_{2}: 23 / 11 / 92$ to $12 / 05 / 93$ & $(0.003)$ & $(0.29)$ & \\
& -7.483 & -2.633 & \\
$\mathrm{~d}_{3}: 13 / 05 / 93$ to $05 / 03 / 95$ & $(-0.44)$ & $(-0.28)$ & 6.050 \\
& 11.203 & 12.814 & $(4.19)^{*}$ \\
$\beta_{1}$ & $(1.74)^{* * *}$ & $(2.097)^{* *}$ & -1.187 \\
& -3.798 & -3.974 & $(-42.83)^{*}$ \\
$\beta_{2}$ & $(-2.05)^{* *}$ & $(-15.54)^{*}$ & 0.079 \\
& -0.752 & -0.286 & $(0.44)$ \\
$\beta_{3}$ & $(-0.96)$ & $(-0.58)$ & -0.724 \\
& 2.524 & 0.904 & $(-4.21)^{*}$ \\
$\mathrm{R}-$-squared & $(1.37)$ & $(0.70)$ & 0.99 \\
$\mathrm{~N}$ & 0.27 & 0.86 & 208 \\
\hline
\end{tabular}

Notes: $\left(x_{t+m}-x_{t}\right) / m \mathrm{~d} t=\sum_{j} \beta_{0 j} d_{j}+\beta_{1} x_{t}+\beta_{2} \Delta_{\text {pte }}^{m}+\beta_{3} \Delta_{\text {esp }}^{m}+\varepsilon_{t+m}$

${ }^{\dagger}$ OLS on equation (2) with Newey-West standard errors allowing for both serial correlation and heteroscedasticity. Regressand is $\left(x_{t+m}-x_{t}\right) / m \mathrm{~d} t$ (\% a year), with $m \mathrm{~d} t=21 / 254$ for one month, $m \mathrm{~d} t=64 / 254$ for three months and $m \mathrm{~d} t=1$ for one year (this corresponds to $m$ equal to 21,64 and 254 daily observations and $\mathrm{d} t$ equal to $1 / 254) . d_{j}$ is a dummy variable for each period between realignments. The first and second periods for the one year horizon are too short to be estimated.

*Significant at the $1 \%$ level

** Significant at the $5 \%$ level

*** Significant at the $10 \%$ level

t-stats shown in brackets

interest rates, would help to clarify whether mimetic behaviour is likely to have occurred.

2 Statistical problems plague the results. It is possible to admit that the effectiveness of the Portuguese monetary policy as well as the Spanish influence may not always have had the same intensity, nor the same sign throughout the short period analysed, resulting in the inaccuracy of the $\beta_{2}$ and $\beta_{3}$ estimates. $^{7}$ On the other hand, it is also possible that

\footnotetext{
${ }^{7}$ As seen in Section II, in order to estimate the 1-year regression only the observations from 13 May 1993 (the date of the second realignment of the Escudo) to 5 March 1994 (one year before the third realignment of the Escudo) were kept. This shorter period of time corresponds to the longest sub period of Iberian exchange rate stability. This could explain the non-significant $\beta_{2}$ and $\beta_{3}$ in the one-month and three-month regressions and the significant $\beta_{3}$ in the one-year regression.
} 
Table 2: Exchange Rate Depreciation Within the Band with Interest Rate Differentials as Independent Variables ${ }^{\dagger}$

\section{DEM-ESP}

\begin{tabular}{lccc}
\hline & 1 month & 3 months & 1 year \\
\hline $\mathrm{d}_{1}: 19 / 06 / 89$ to $16 / 09 / 92$ & -5.440 & -5.968 & 1.005 \\
& $(-0.80)$ & $(-1.72)^{* * *}$ & $(0.93)$ \\
$\mathrm{d}_{2}: 17 / 09 / 92$ to $22 / 11 / 92$ & 24.236 & & \\
& $(3.37)^{*}$ & & \\
$\mathrm{~d}_{3}: 23 / 11 / 92$ to $12 / 05 / 93$ & 3.613 & 1.857 & \\
& $(0.39)$ & $(0.42)$ & 7.611 \\
$\mathrm{~d}_{4}: 13 / 05 / 93$ to $05 / 03 / 95$ & 18.864 & 14.754 & $(9.19)^{*}$ \\
$\beta_{1}$ & $(2.87)^{*}$ & $(5.07)^{*}$ & -0.724 \\
& -2.976 & -2.636 & $(-8.86)^{*}$ \\
$\beta_{3}$ & $(-2.09)^{* *}$ & $(-5.18)^{*}$ & -0.694 \\
& -0.660 & -0.391 & $(-3.45)^{*}$ \\
$\mathrm{R}-$ squared & $(-0.75)$ & $(-0.52)$ & 0.81 \\
$\mathrm{~N}$ & 0.14 & 0.41 & 646 \\
\hline
\end{tabular}

Notes: $\left(x_{t+m}-x_{t}\right) / m \mathrm{~d} t=\sum_{j} \beta_{0 j} d_{j}+\beta_{1} x_{t}+\beta_{3} \Delta_{\text {esp }}^{m}+\varepsilon_{t+m}$

${ }^{\dagger}$ OLS on equation (2) with Newey-West standard errors allowing for both serial correlation and heteroscedasticity. Regressand is $\left(x_{t+m}-x_{t}\right) / m \mathrm{~d} t$ (\% a year), with $m \mathrm{~d} t=21 / 254$ for one month, $m \mathrm{~d} t=64 / 254$ for three months and $m \mathrm{~d} t=1$ for one year (this corresponds to $m$ equal to 21,64 and 254 daily observations and $d t$ equal to $1 / 254) . d_{j}$ is a dummy variable for each period between realignments. The second period for the three months horizon and the second and third periods for one year horizon are too short to be estimated.

*Significant at the $1 \%$ level

** Significant at the $5 \%$ level

$* * *$ Significant at the $10 \%$ level

t-stats shown in brackets

we have strongly correlated regressors due to the interdependent Iberian interest rates.

An understanding of the influence of interest rate differentials on the behaviour of the rate of depreciation of the Escudo within the band therefore requires the continuation of this study along two other tracks. On the one hand, possible changes in the sign and size of the coefficients $\beta_{2}$ and $\beta_{3}$ need to be looked for throughout the period of participation in the EMS. From this perspective, new estimations were made of the rates of depreciation of the Escudo and Peseta, either by allowing the coefficients $\beta_{2}$ and $\beta_{3}$ to vary between sub-periods or by rearranging the sub-periods and causing them to coincide with the different phases of credibility of the Escudo. 
On the other hand, possible relationships of interdependence need to be highlighted between the evolution of Spanish and Portuguese interest rates. In this sense, we need to analyse the correlation between the two series of interest rates and the variation of this correlation throughout the period, as well as the possible causality relation (in Granger's sense) between the interest rate variations in the two countries.

\section{In search of different characteristic periods marking the influence of} interest rate differentials on the behaviour of the Escudo within the band To test the influence of interest rate differentials on the behaviour of the Escudo within the band, the rate of depreciation of the Escudo was estimated for a one-month horizon, for each sub-period between realignments, using equation (3) below:

$$
\left(x_{t+21}-x_{t}\right) /(21 / 254)=\beta_{0}+\beta_{1} x_{t}+\beta_{2} \Delta_{p t e}^{m}+\beta_{3} \Delta_{e s p}^{m}+\varepsilon_{t+21}
$$

Results are presented in Table 3. Two initial statistical conclusions emerge from these results. First, the instability of the $\beta_{2}$ coefficient is evident. Second, the low model performance for the 14/04/1992-22/11/1992 subperiod: if one uses the conventional 5\% significance level, the explanatory variables are useless. However, during the other two regimes, that is, between the first and the third Escudo realignments, the coefficients $\beta_{2}$ and $\beta_{3}$ were both negative, suggesting that the increase in Spanish and Portuguese interest rates strengthened the Escudo within the band.

As far as the Portuguese rates were concerned, the differential with Germany $\left(\beta_{2}\right)$ was negative, as expected. ${ }^{8}$ This minus sign does in fact confirm the relationship between the interest rate differential and the exchange rate predicted by the model of target zones, whenever the exchange rate band is credible: in this case, an increase in the differential (i.e. an increase in domestic interest rates) strengthens the currency within the band. In our opinion, the minus sign confirms that the management of interest rates in Portugal has been largely governed by the objective of

\footnotetext{
${ }^{8}$ Given that we have eliminated the observations preceding a realignment over a period that was shorter than the horizon considered for the estimated depreciation rate, the information relating to the periods when attacks against the Escudo were not successfully counteracted by the monetary authorities was also eliminated (otherwise the realignment shouldn't have happened). This means that, very probably, we have underestimated the possible existence of a positive relationship between the interest rate differential in relation to Germany and the expected Escudo depreciation rate. In other words, we have over-estimated the efficiency of the interest rate policy. It is therefore normal to obtain a negative $\beta_{2}$ coefficient for the full period, which expresses the fact that a rise in interest rates strengthens the currency, except in periods of particular tension in the foreign exchange market that precedes a change in regime.
} 
Table 3: Exchange Rate Depreciation Within the Band for Each Period between Realignments (One Month Horizon) ${ }^{\dagger}$

DEM-PTE

\begin{tabular}{lccc}
\hline & $14 / 04 / 92$ to $22 / 11 / 92$ & $23 / 11 / 92$ to $12 / 05 / 93$ & $13 / 05 / 93$ to $05 / 03 / 95$ \\
\hline$\beta_{0}$ & 1.381 & 25.432 & 34.930 \\
$\beta_{1}$ & -1.528 & -1.642 & -4.919 \\
& $(-1.61)$ & $(-2.60)^{* *}$ & $(-14.08)^{*}$ \\
$\beta_{2}$ & 1.239 & -1.490 & -2.240 \\
& $(1.729)^{* * *}$ & $(-4.618)^{*}$ & $(-5.27)^{*}$ \\
$\beta_{3}$ & -0.217 & -1.187 & -1.54 \\
& $(-0.12)$ & $(-1.68)^{* * *}$ & $(-1.43)$ \\
R-squared & 0.04 & 0.29 & 0.40 \\
$\mathrm{~N}$ & 135 & 100 & 441 \\
\hline
\end{tabular}

Notes: $\left(x_{t+21}-x_{t}\right) /(21 / 254)=\beta_{0}+\beta_{1} x_{t}+\beta_{2} \Delta_{\text {pte }}^{m}+\beta_{3} \Delta_{\text {esp }}^{m}+\varepsilon_{t+21}$

${ }^{\dagger}$ OLS with Newey-West standard errors allowing for both serial correlation and heteroscedasticity. Regressand is $\left(x_{t+21}-x_{t}\right) / m \mathrm{~d} t$ (\% a year), with $m \mathrm{~d} t=21 / 254$ corresponding to one month.

* Significant at the $1 \%$ level

** Significant at the $5 \%$ level

*** Significant at the $10 \%$ level

t-stats shown in brackets

exchange rate stabilization and that, most of the time, this policy has proved to be effective.

As far as the influence of Spanish interest rates on the Escudo is concerned, the hypothesis that the Peseta has an influence on the Escudo cannot be rejected, at least for the period from November 1992 to May 1993 and the $10 \%$ significance level.

Thus, when taken together, the coefficients $\beta_{2}$ and $\beta_{3}$ seem to support, for the one-month time horizon, in the second and third sub-periods, the results that were obtained with the estimation of the rate of depreciation of the Escudo for a one-year horizon (Table 1). The credibility of the Escudo fluctuation band was guaranteed by the rise in Portuguese and Spanish interest rates. The rise in Spanish rates probably operated (or was perceived by Portuguese authorities) as a constraint on monetary policy in Portugal.

Nevertheless, we cannot be satisfied with these results. In fact, given the aforementioned $\beta_{2}$ parameter instability and the irrelevance of the first subperiod regression, we must be somewhat guarded about the conclusions put forward.

As a result, the question arose as to whether the breakdown into subperiods marked by the occurrence of a realignment was in fact the best way to understand the possible changes in the influences of interest rate differentials on the depreciation rate of the Escudo. In fact, the realignments 
do not seem to mark any significant changes in the evolution of the Escudo within the band. Using 'simple' credibility tests,' Abreu (1999a) drew conclusions as regards the relevance of three other sub-periods. The first one, from the date when the Escudo joined the ERM to August 1992, was characterized by strong and stable credibility; the second, between September 1992 and July 1993, was marked by a growing nervousness in the markets (increased volatility), with credibility being restored in leaps and bounds and only temporarily after each realignment; the third period, between July 1993 and March 1995, was marked by an extreme lack of credibility of the Escudo band, which was much greater than that of the Peseta.

We therefore re-estimated the depreciation rate of the Escudo and the Peseta within the band, for all time horizons, in keeping with equation (2), this time taking into consideration the sub-periods from Abreu (1999a). We also reestimated the rate of depreciation of the Escudo, for the time horizon of one month, separately for each sub-period between realignments, in keeping with equation (3). The results of these estimations are shown in Tables 4, 5 and 6.

Results in Table 4 show remarkable differences with regard to the identification of regimes. The coefficient $\beta_{03}$ is now significant for all time horizons, and $\beta_{02}$ is significant for the 3 -month horizon. On the other hand, by taking these periods into account, we were able to identify more clearly the influence that, as a whole, pressures exerted on the Peseta have on the behaviour of the Escudo within the band. The $\beta_{3}$ coefficient for the Escudo is negative and statistically significant for time horizons of 3 months and one year. It therefore seems possible to confirm the hypothesis of a contagion effect of the Peseta on the Escudo for these horizons. The Spanish authorities increased their interest rates to strengthen the Peseta, an action in which they were successful (for $\beta_{3}$ is also negative for the Peseta, Table 5), and the Portuguese authorities accompanied them in order to prevent the Escudo from being attacked, with equal success. Table 6 allows us to determine the variation, between the different sub-periods, in the influence of interest rates on the expected Escudo depreciation rate for one month. The coefficients $\beta_{2}$ and $\beta_{3}$ are significant for the first two sub-periods. ${ }^{10}$ Until August 1992, $\beta_{2}$ was negative while $\beta_{3}$ was positive. This combination represents, a priori, a competitive relationship between the two currencies: an increase in Portuguese interest rates strengthens the Escudo, while Spanish

\footnotetext{
${ }^{9}$ In the 'simple test', the devaluation expectation is computed by adjusting interest rate differentials for the maximum and minimum rates of possible currency depreciation within the band. This method has the advantage of taking into account all the observations, but, on the other hand, the corresponding test of credibility of the exchange rate band is frequently inconclusive.

${ }^{10}$ Considering a $10 \%$ significance level.
} 
Table 4: Exchange Rate Depreciation Within the Band using a 'Dummy' for Each Regime ${ }^{\dagger}$

\section{DEM-PTE}

\begin{tabular}{lccc}
\hline & 1 month & 3 months & 1 year \\
\hline $\mathrm{d}_{1}: 14 / 04 / 92$ to $18 / 08 / 92$ & -2.704 & 8.138 & \\
& $(-0.19)$ & $(1.13)$ & \\
$\mathrm{d}_{2}: 19 / 08 / 92$ to $08 / 07 / 93$ & 11.636 & 16.669 & \\
& $(0.89)$ & $(3.16)^{*}$ & 8.676 \\
$\mathrm{~d}_{3}: 09 / 07 / 93$ to $05 / 03 / 95$ & 23.915 & 25.103 & $(6.58)^{*}$ \\
& $(2.16)^{* *}$ & $(5.80)^{*}$ & -1.193 \\
$\beta_{1}$ & -5.124 & -4.727 & $(-67.27)^{*}$ \\
& $(-2.33)^{* *}$ & $(-8.12)^{*}$ & -0.390 \\
$\beta_{2}$ & -0.867 & -0.469 & $(-2.51)^{* *}$ \\
& $(-1.18)$ & $(-1.10)$ & -0.871 \\
$\beta_{3}$ & 0.160 & -2.045 & $(-4.70)^{*}$ \\
& $(0.11)$ & $(-2.24)^{* *}$ & 0.96 \\
$\mathrm{R}-$ squared & 0.29 & 0.82 & 169 \\
$\mathrm{~N}$ & 676 & 547 & \\
\hline
\end{tabular}

Notes: $\left(x_{t+m}-x_{t}\right) / m \mathrm{~d} t=\sum_{j} \beta_{0 j} d_{j}+\beta_{1} x_{t}+\beta_{2} \Delta_{\text {pte }}^{m}+\beta_{3} \Delta_{\text {esp }}^{m}+\varepsilon_{t+m}$

${ }^{\dagger}$ OLS on equation (2) with Newey-West standard errors allowing for both serial correlation and heteroscedasticity. Regressand is $\left(x_{t+m}-x_{t}\right) / m \mathrm{~d} t$ (\% a year), with $m \mathrm{~d} t=21 / 254$ for one month, $m \mathrm{~d} t=64 / 254$ for three months and $m \mathrm{~d} t=1$ for one year (this corresponds to $m$ equal to about 21 , 64 and 254 daily observations and $d t$ equal to $1 / 254) . d_{j}$ is a dummy variable for each period between realignments. The first and second periods for one year horizon are too short to be estimated.

*Significant at the $1 \%$ level

** Significant at the $5 \%$ level

$* * *$ Significant at the $10 \%$ level

t-stats shown in brackets

rates exert pressure in the opposite direction. A rise in interest rates in the neighbouring country would expose Portugal to an outflow of capital that would accentuate the depreciation of the Escudo. Between August 1992 and July 1993, $\beta_{2}$ and $\beta_{3}$ were both negative. We therefore find once again the situation envisaged by the hypothesis of a credible band guaranteed by an effective monetary policy which closely follows what is happening in Spain.

In the third sub-period, after August 1993, $\beta_{2}$ and $\beta_{3}$ were not statistically significant.

\section{Brief assessment of the correlation between Portuguese and Spanish interest rates and search for causalities}

An assessment of the correlation, as well as possible relationships of causality, between Portuguese and Spanish interest rates, would seem indispensable for the interpretation of the aforementioned results. 
Table 5: Exchange Rate Depreciation Within the Band taking a 'Dummy' for Each Regime ${ }^{\dagger}$

\section{DEM-ESP}

\begin{tabular}{lccc}
\hline & 1 month & 3 months & 1 year \\
\hline $\mathrm{d}_{1}: 19 / 06 / 89$ to $18 / 08 / 92$ & -3.636 & -5.126 & 0.973 \\
& $(-0.63)$ & $(-1.26)$ & $(0.80)$ \\
$\mathrm{d}_{2}: 19 / 08 / 92$ to $08 / 07 / 93$ & 11.43 & 7.933 & \\
& $(1.34)$ & $(1.52)$ & 7.642 \\
$\mathrm{~d}_{3}: 09 / 07 / 93$ to $05 / 03 / 95$ & 18.708 & 16.048 & $(8.75)^{*}$ \\
& $(2.87)^{*}$ & $(4.82)^{*}$ & -0.730 \\
$\beta_{1}$ & -2.715 & -2.768 & $(-6.27)^{*}$ \\
$\beta_{3}$ & $(-2.19)^{* *}$ & $(-4.08)^{*}$ & -0.692 \\
& -0.867 & -0.658 & $(-3.34)^{*}$ \\
$\mathrm{R}$-squared & $(-0.93)$ & $(-0.83)$ & 0.74 \\
$\mathrm{~N}$ & 0.12 & 0.37 & 607 \\
\hline
\end{tabular}

Notes: $\left(x_{t+m}-x_{t}\right) / m \mathrm{~d} t=\sum_{j} \beta_{0 j} d_{j}+\beta_{1} x_{t}+\beta_{3} \Delta_{\text {esp }}^{m}+\varepsilon_{t+m}$

${ }^{\dagger}$ OLS on equation (2) with Newey-West standard errors allowing for both serial correlation and heteroscedasticity. Regressand is $\left(x_{t+m}-x_{t}\right) / m \mathrm{~d} t$ (\% a year), with $m \mathrm{~d} t=21 / 254$ for one month, $m \mathrm{~d} t=64 / 254$ for three months and $m \mathrm{~d} t=1$ for one year (this corresponds to $m$ equal to about 21 , 64 and 254 daily observations and $d t$ equal to $1 / 254$ ). $d_{j}$ is a dummy variable for each period between realignments. The second period for the one year horizon is too short to be estimated.

*Significant at the $1 \%$ level

** Significant at the $5 \%$ level

*** Significant at the $10 \%$ level

t-stats shown in brackets

By observing the coefficients of correlation between the Portuguese and Spanish interest rates presented in Table 7, the following may be concluded:

1 That there is an important positive correlation between Portuguese and Spanish interest rates throughout the whole period of the Escudo's participation in the ERM;

2 That this link is stronger whenever the maturity of the rates is longer;

3 That the strength of this link seems to vary greatly throughout the period of the Escudo's participation in the ERM. After being very strong until July 1993, it diminished thereafter, to the point of becoming negative for time horizons of one month and three months.

The results referred to above attest that there is a strong interdependence ${ }^{11}$ between Portuguese and Spanish interest rates, and that this actually

\footnotetext{
${ }^{11}$ We must bear in mind that correlation coefficients may be biased upward during periods of high volatility (Forbes and Rigobon 1999), though this may be less of a problem with interest rates compared to exchange rates or other financial variables.
} 
Table 6: Exchange Rate Depreciation within the Band for each 'Regime' (One Month Horizon) ${ }^{\dagger}$

\section{DEM-PTE}

\begin{tabular}{lccc}
\hline & $14 / 04 / 92$ to $18 / 08 / 92$ & $19 / 08 / 92$ to $08 / 07 / 93$ & $09 / 07 / 93$ to $05 / 03 / 95$ \\
\hline$\beta_{0}$ & -177.501 & 38.347 & 38.115 \\
$\beta_{1}$ & -11.378 & -1.566 & -10.120 \\
& $(-8.16)^{*}$ & $(-2.29)^{* *}$ & $(-23.94)^{*}$ \\
$\beta_{2}$ & -1.373 & -1.824 & -0.251 \\
& $(-1.72)^{* * *}$ & $(-3.36)^{*}$ & $(-0.91)$ \\
$\beta_{3}$ & 57.587 & -2.565 & -0.099 \\
& $(14.42)^{*}$ & $(-2.97)^{*}$ & $(-0.15)$ \\
R-squared & 0.76 & 0.23 & 0.63 \\
$\mathrm{~N}$ & 88 & 186 & 402 \\
\hline
\end{tabular}

Notes: $\left(x_{t+21}-x_{t}\right) /(21 / 254)=\beta_{0}+\beta_{1} x_{t}+\beta_{2} \Delta_{\text {pte }}^{21}+\beta_{3} \Delta_{\text {esp }}^{21}+\varepsilon_{t+21}$

${ }^{\dagger}$ OLS with Newey-West standard errors allowing for both serial correlation and heteroscedasticity. Regressand is $\left(x_{t+21}-x_{t}\right) / m \mathrm{~d} t$ (\% a year), with $m \mathrm{~d} t=21 / 254$ corresponding to one month.

* Significant at the $1 \%$ level

**Significant at the $5 \%$ level

$* * *$ Significant at the $10 \%$ level

t-stats shown in brackets

Table 7: Pearson Correlation Coefficient between the Portuguese and Spanish/German Interest Rates on the Euromarket

\begin{tabular}{|c|c|c|c|c|c|}
\hline & $\begin{array}{c}14 / 04 / 92 \text { to } \\
05 / 03 / 95\end{array}$ & $\begin{array}{c}14 / 04 / 92 \text { to } \\
08 / 07 / 93\end{array}$ & $\begin{array}{c}09 / 07 / 93 \text { to } \\
05 / 03 / 95\end{array}$ & $\begin{array}{c}14 / 04 / 92 \text { to } \\
18 / 08 / 92\end{array}$ & $\begin{array}{c}19 / 08 / 92 \text { to } \\
08 / 07 / 93\end{array}$ \\
\hline \multicolumn{6}{|c|}{ Portuguese versus Spanish } \\
\hline 1 month & $\begin{array}{c}0.469^{*} \\
(0.033)\end{array}$ & $\begin{array}{c}0.558^{*} \\
(0.047)\end{array}$ & $\begin{array}{c}-0.180^{*} \\
(0.048)\end{array}$ & $\begin{array}{l}0.178^{* * *} \\
(0.106)\end{array}$ & $\begin{array}{c}0.382^{*} \\
(0.061)\end{array}$ \\
\hline 3 months & $\begin{array}{c}0.517^{*} \\
(0.032)\end{array}$ & $\begin{array}{c}0.625^{*} \\
(0.044)\end{array}$ & $\begin{array}{c}-0.153^{*} \\
(0.048)\end{array}$ & $\begin{array}{c}0.293^{*} \\
(0.103)\end{array}$ & $\begin{array}{c}0.456^{*} \\
(0.059)\end{array}$ \\
\hline 1 year & $\begin{array}{c}0.680^{*} \\
(0.027)\end{array}$ & $\begin{array}{c}0.825^{*} \\
(0.032)\end{array}$ & $\begin{array}{c}0.256^{*} \\
(0.047)\end{array}$ & $\begin{array}{c}0.479^{*} \\
(0.095)\end{array}$ & $\begin{array}{c}0.676^{*} \\
(0.049)\end{array}$ \\
\hline \multicolumn{6}{|c|}{ Portuguese versus German } \\
\hline 1 month & $\begin{array}{c}0.650^{*} \\
(0.028)\end{array}$ & $\begin{array}{r}-0.031 \\
(0.057)\end{array}$ & $\begin{array}{c}0.109^{* *} \\
(0.049)\end{array}$ & $\begin{array}{r}-0.072 \\
(0.109)\end{array}$ & $\begin{array}{c}0.315^{*} \\
(0.063)\end{array}$ \\
\hline 3 months & $\begin{array}{c}0.663^{*} \\
(0.028)\end{array}$ & $\begin{array}{c}0.018 \\
(0.057)\end{array}$ & $\begin{array}{c}-0.049 \\
(0.049)\end{array}$ & $\begin{array}{c}-0.112 \\
(0.108)\end{array}$ & $\begin{array}{c}0.351^{*} \\
(0.063)\end{array}$ \\
\hline
\end{tabular}

Notes: Interest rates are daily observations on annualized bid rates on euromarket deposits in escudos and in pesetas. Standard deviations shown in brackets.

*Significant at $1 \%$

** Significant at $5 \%$

$* * *$ Significant at $10 \%$ 
increased after the 1992 crises. This interdependence remained positive until the widening of the bands in 1993, a period in which both the Peseta and the Escudo were under pressure. After July 1993, the correlation becomes negative, in a period when only the Portuguese Escudo was under attack.

The interdependence between Escudo and Peseta interest rates can be refined by using econometric techniques that look for causal relations. It is important to stress that the causality established in this way does not necessarily reflect the underlying existence of a fundamental economic law. The econometric causality that links two variables together simply indicates that knowledge of past values of one variable improves prediction ('cause') with regard to the other.

The results of the causality tests applied to the period from 6 April 1992 to 7 March 1995 are shown in Table 8. These results suggest that there is a relationship of instantaneous causality, in one direction only, from the Peseta to the Escudo, after the Escudo's integration into the exchange rate mechanism. No other relationship of causality can be confirmed, either in the same direction (but nonetheless considering past values), or in the opposite direction (from the Escudo to the Peseta).

\section{Principal Conclusions on the Rate of Depreciation of the Escudo within the Band}

With regard to the influence exercised by interest rate differentials, and therefore by monetary policy, on the expected rate of depreciation of the

Table 8: Granger Causality between Portuguese and Spanish Interest Rates - One Month Horizon

\begin{tabular}{|c|c|c|c|}
\hline & Equation $^{\ddagger}$ & Equation $^{\S}$ & Equation \\
\hline \multicolumn{4}{|c|}{ Spain $>$ Portugal $^{\|}$} \\
\hline $\begin{array}{l}\text { F-stat. } \\
\text { (probability) }\end{array}$ & $\begin{array}{l}1.715 \\
(0.126)\end{array}$ & $\begin{array}{l}1.043 \\
(0.418)\end{array}$ & $\begin{array}{c}1.864^{*} \\
(0.046)\end{array}$ \\
\hline \multicolumn{4}{|c|}{ Portugal \ Spain } \\
\hline $\begin{array}{l}\text { F-stat. } \\
\text { (probability) }\end{array}$ & $\begin{array}{l}3.388 \\
(0.004)\end{array}$ & $\begin{array}{c}2.531 \\
(0.007)\end{array}$ & $\begin{array}{c}3.387 \\
(0.003)\end{array}$ \\
\hline
\end{tabular}

\footnotetext{
${ }^{\dagger}$ We use the Sargent's Tests to evaluate Granger causality. The following equations were estimated:

${ }^{\ddagger} Y_{t}=a_{0}+\sum_{i=1}^{n} a_{i} Y_{t-i}+\varepsilon_{t}$ with $E\left(\varepsilon_{t}\right)=0, E\left(\varepsilon_{t}, \varepsilon_{t-1}\right)=0$.

${ }^{\S} Y_{t}=a_{0}+\sum_{i=1}^{n} a_{i} Y_{t-i}+\sum_{i=1}^{n 1}+b_{i} X_{t-i}+\varepsilon_{t}$ with $E\left(\varepsilon_{t}\right)=0, E\left(\varepsilon_{t}, \varepsilon_{t-1}\right)=0$.

${ }^{\uparrow} Y_{t}=a_{0}+\sum_{i=1}^{n} a_{i} Y_{t-i}+\sum_{i=0}^{n 1}+b_{i} X_{t-i}+\varepsilon_{t}$ with $E\left(\varepsilon_{t}\right)=0, E\left(\varepsilon_{t}, \varepsilon_{t-1}\right)=0$.

"'Spain Portugal' means that Spanish interest rates Granger-cause Portuguese ones.

Tests have been applied to interest rate monthly average changes between 6/4/92 and 7/3/95. Interest rates are daily observations on annualized bid rates for 1-month euromarket deposits.

${ }^{*}$ means that the hypothesis of no-causality must be rejected for a $5 \%$ significance level.
} 
Escudo within the band, the principal results obtained allow us to deduce that the influence of the variation in (Portuguese and Spanish) interest rates on the position of the Escudo within the band did not have the same sign throughout the EMS period. In fact, for the time horizon of one month, results in Tables 1 and 4 show no significant $\beta_{2}$ and $\beta_{3}$ values, if one considers these coefficients fixed for the entire EMS period.

For the one-month horizon, statistically significant coefficients of interest rate differentials were only obtained in the case of separate estimations of the depreciation rate within each sub-period. Results in Table 6 lead us to conclude that:

1 From April 1992, when the Escudo joined the ERM until the summer of 1993, Portuguese monetary policy could be regarded as successful (in relation to the exchange rate objective); the increase in domestic interest rates making it possible to strengthen the Escudo. In fact, the $\beta_{2}$ coefficient, which expresses the efficiency of monetary policy in relation to the exchange rate objective, is negative during this period. ${ }^{12}$

2 During a very short period only (between April and August 1992), the negative $\beta_{2}$ coefficient $^{13}$ is linked to a positive $\beta_{3}$. This situation would seem to indicate that during the first months of the Escudo's participation in the ERM, monetary policy was effective and not constrained by the behaviour of the Spanish monetary authorities, with the relationship between the currencies demonstrating the typical features of a competitive relationship.

3 Between August 1992 and July 1993, both $\beta_{2}$ and $\beta_{3}$ are negative and significant. It would therefore seem that, during this phase, monetary policy continued to show a tendency to be effective in Portugal (since the increase in Portuguese rates reduced expectations of a depreciation of the Escudo), although it was nonetheless largely determined by the behaviour of the Spanish authorities. A rise in interest rates in Spain (in view of the strengthening of the Peseta) was quickly followed by Portuguese authorities, who thus prevented the Escudo from being attacked. A study of the interdependence between the interest rates of the two countries seems to support this interpretation. In fact, we found a strong correlation between the interest rates of the two countries during this period. Furthermore, the instantaneous causality noted from the Peseta interest rates to those of the Escudo also seems to confirm this idea.

\footnotetext{
${ }^{12}$ This apparent efficiency of monetary policy does, however, need to be viewed with a certain amount of reservation, since we have eliminated the observations preceding a realignment.

${ }^{13}$ Significant at the $10 \%$ level.
} 
4 In the first two periods, in which the coefficients were seen to be significant, ${ }^{14}$ the coefficient associated with Spanish interest rates was always stronger, which would seem to account for the intensity of the exchange rate constraint exerted by Spain.

5 After July 1993, it is not possible to make any judgement; either about the influence of Portuguese interest rates or the influence of Spanish rates on the behaviour of the Escudo within the band, since neither $\beta_{2}$ nor $\beta_{3}$ is significant. As far as Portuguese interest rates are concerned, this fact seems to demonstrate a tendency towards a reduction in the efficiency of the interest rate policy. In the case of the Spanish influence, the fact that $\beta_{3}$ is not statistically significant confirms that there was no real symbiosis in the behaviour of the exchange rates of the two currencies. In this phase, and unlike the earlier ones, the Peseta was not under attack (the Peseta was simply hovering close to the band's ceiling of $6 \%$ throughout most of this period); it was the Escudo that was constantly subject to tensions in the foreign exchange market. The results for $\beta_{3}$ in this period, coupled with the results obtained for previous periods, seem to suggest the existence of a one-way transfer of the weakness of the Peseta onto that of the Escudo. The recursive estimation of $\beta_{3}$ (results not shown) seems to confirm this hypothesis, namely that the influence of the Peseta on the Escudo was exerted at moments when the Peseta was 'weak', and not throughout each subperiod analysed here.

\section{Estimations of the Expected Rate of Devaluation}

The expected rate of devaluation of the Escudo and the Peseta in relation to the Deutschmark is obtained by deducting the expected rate of depreciation within the band from the interest rate differential on the euromarket between the currency of the country being considered and that of Germany, in keeping with equation (1).

On the one hand, the longer the horizon of expectation, the higher the expected rate of devaluation, which is natural given that a realignment is all the more likely to occur when the time period considered is longer. On the other hand, the shorter the horizon of expectation, the higher the volatility of the expected rate of devaluation, which is explained by the relatively high volatility of short rates in comparison with long rates.

\footnotetext{
${ }^{14}$ At least at the $10 \%$ level.
} 
Let us now focus on the shortest horizon: one month. Figure 2 retraces the evolution of the expected rate of devaluation (by time unit) of the Escudo and the Peseta against the Deutschmark for the time horizon of one month. The estimations chosen for the depreciation rate are those shown in Tables 1 and $2 .{ }^{15}$

Three sub-periods can be clearly identified.

1 The first of these sub-periods, April to August 1992, is marked by a weak volatility of the devaluation rate. On the other hand, the devaluation rate, which is negative throughout the sub-period, expresses a strong level of credibility in regard to the exchange rate band. This credibility of the Escudo exchange rate band was only to be

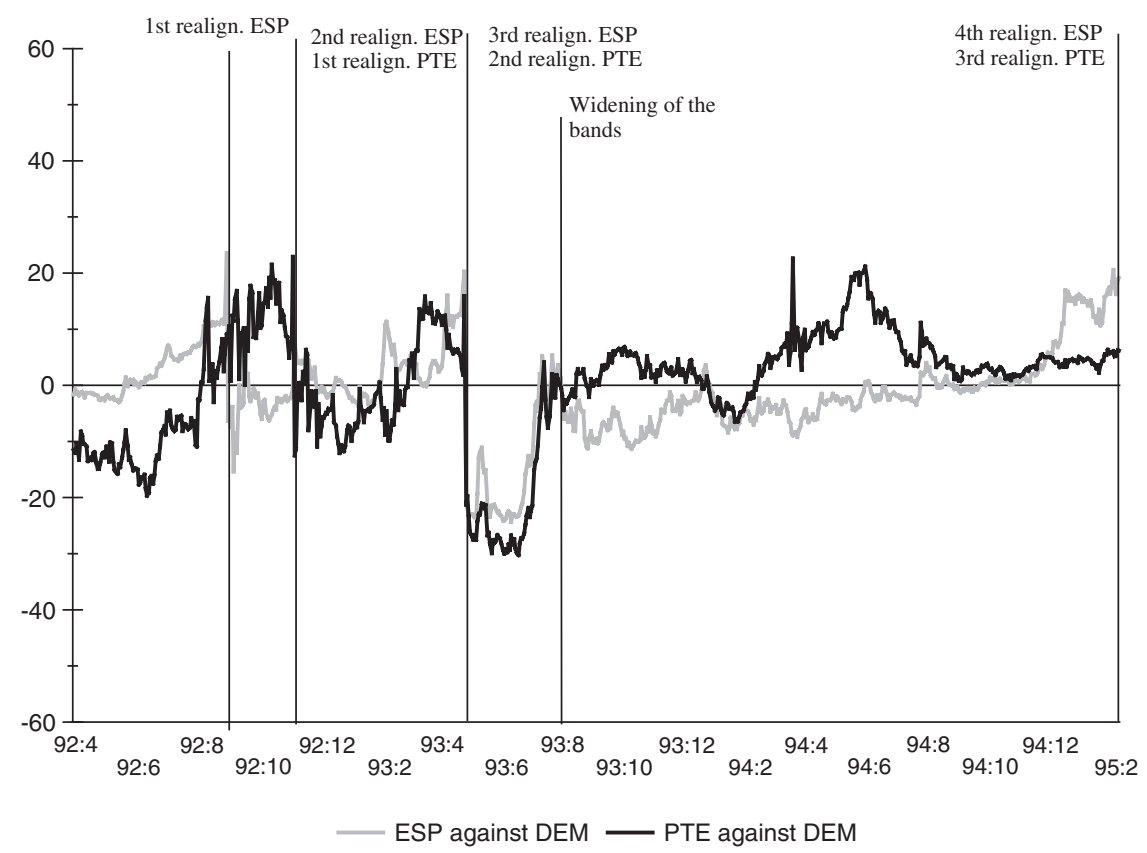

Figure 2: Expected rate of devaluation for the time horizon of one month

\footnotetext{
${ }^{15}$ This choice arises from the fact that the estimation of equation (2) displays better quality than that centred exclusively on the differential between the exchange rate and the central parity $\left(x_{\mathrm{t}}\right)$. Opting for sub-periods between realignments vis-à-vis 'regimes' allows us, first of all, not to introduce information gaps within each sub-period (which would inevitably influence the constants associated with each period), for, in order to avoid sudden leaps in the exchange rate within the band (the depreciation rate is conditionally estimated in the absence of a realignment), the estimation requires the elimination of ' $m$ ' observations before each realignment. Secondly, this choice makes it easier to establish comparisons with the behaviour of other currencies.
} 
seen again in a somewhat temporary fashion after the realignment of May 1993.

2 After August 1992, this state of grace enjoyed by the Escudo came to a sudden end. During this second sub-period, between August 1992 and July 1993, phases of credibility followed on from periods when a realignment was seen as imminent, i.e. phases in which the only common feature was an enormous volatility of the expected rate of devaluation. The devaluation of November 1992 brought little more than a temporary respite, for the rate of devaluation only briefly remained below zero. After the realignment, the rate of devaluation shot upwards again, becoming positive after March 1993. Credibility was once more temporarily restored for a brief two-month period after the realignment of May 1993.

3 Finally, in the third sub-period, between July 1993 and the realignment in March 1995, there was an almost continuous expectation of a devaluation of the Escudo, while, at the same time, its volatility was reduced. During this long period of roughly 20 months, two crises in the credibility of the Escudo can be distinguished: the first one in October 1993, the other in June 1994.

An analysis of Figure 2 allows us to compare the evolution of the expected rates of devaluation of the Escudo and the Peseta. There are several points that should be pointed out here:

1 It clearly seems that the credibility of the bands of the two currencies evolved in a practically concerted fashion following the second realignment of the Peseta (first of the Escudo) and until the widening of the bands, in August 1993. Thereafter, their evolutions diverged quite dramatically.

2 The moments of greatest weakness of the Peseta led almost systematically to a realignment of parities, which therefore brought with them a devaluation of the Escudo. The only exception was the realignment of September 1992, after which expectations of a devaluation of the Escudo remained very high.

3 The lack of credibility of the Escudo exchange rate band, which had increased in the second half of 1993 and continued throughout 1994, does not seem to have contaminated the credibility of the Peseta. The realignment of March 1995 only arose after the rapid rise in the expected rate of devaluation of the Peseta after December 1994 and at a time when the Escudo seemed to have partly regained some of its lost credibility. 


\section{Conclusion}

The preceding analysis shows that the participation of the Escudo in the ERM was marked by a repeated lack of credibility after the autumn of 1992. In particular, the $\pm 6 \%$ Escudo exchange rate band, which had been implicitly defended by the Portuguese monetary authorities since August 1993, showed itself to be continuously lacking in credibility.

There are some fundamental reasons which justify the speculative attacks suffered by the Portuguese currency in 1992, particularly the overappreciation of the Escudo real exchange rate which accumulated from the second half of the 1980s (Abreu 1999b; Kempa and Nelles 1999; Williamson 2000a). What is more difficult to understand is why the Escudo continued to be under pressure until March 1995, once this real overappreciation had been absorbed by the first two realignments.

A credible explanation for this behaviour is suggested by the strong link noted between the Escudo and the Peseta. Yet, as we have seen, this was not a marriage of the 'for better or worse' type. The Escudo seems to have followed the Peseta when the expected rate of devaluation of the latter moved upwards, but it did not, however, pull the Peseta down with it in its moments of 'weakness', nor did it benefit from mirroring the Peseta in its periods of greater vigour. In other words, it seems that the credibility of the Peseta was not a sufficient condition, but was instead a necessary condition, for the credibility of the Escudo.

As Eichengreen et al. (1997) have clearly pointed out, we speak of contagion in foreign exchange markets when there exists a systematic effect on the probability of a speculative attack which stems from attacks on other currencies, and is therefore an additional effect above and beyond those of domestic 'fundamentals'.

In the Portuguese and Spanish case, this spillover seems to be well explained by the anticipated mimetic behaviour of the Portuguese monetary authorities vis à vis the Spanish monetary authorities. We evaluate this phenomenon as a particular case of the escape clause approach to new models of currency crises.

A country which adheres to a fixed exchange rate arrangement makes that commitment in view of certain benefits. The commitment to maintain the exchange rate within a band is limited, in the sense that the country's policymaker can always exercise the escape clause, i.e. devalue, if the benefits associated with the fixed peg are outweighed by the costs of the same. From this perspective, a currency crisis is a situation in which private agents perceive that monetary authorities are on the brink of abandoning the prevailing exchange rate policy. 
What would seem to be particular to the Portuguese case is that market expectations of the monetary authorities' evaluation of benefits and costs depend mostly on the behaviour of Spanish monetary authorities in response to a speculative attack. If Spanish authorities respond to an attack with a devaluation of the Peseta, it is supposed that this will sharply increase the cost of the prevailing exchange rate policy in Portugal. A devaluation of the Peseta thus leads investors to revise their beliefs in the continuity of the Portuguese commitment to the exchange rate system.

Margarida Abreu

Departamento de Economia

Instituto Superior de Economia e Gestão - U.T.L.

Rua Miguel Lupi, 20,

1200-725 Lisboa,

Portugal

Mabreu@iseg.utl.pt

\section{References}

Abreu, Margarida (1999a), 'As Crises Cambiais do Escudo entre 1992 e 1995', Boletim de Ciências Económicas de Coimbra.

Abreu, Margarida (1999b), 'Exchange Rate Market Tensions in a Small Open Economy during the Transition to EMU: Can Asian Countries Learn from the Portuguese Experience en 1992-1995', Instituto Superior de Economia e Gestão, Economics Department Working Paper, WP7/1999/DE/CISEP, ISSN 0874-4548.

Abreu, Margarida, and Laurence Scialom (2000), 'Prudential Policy and Exchange Rate Regime: The Lessons of the Asian Crisis', in M. Abreu and V. Mendes (eds), What Financial System for the Year 2000? Lisboa: Bolsa de Valores de Lisboa e Porto, 81-108.

Bartolini, Leonardo, and Alessandro Prati (1999), 'Soft Exchange Rate Bands and Speculative Attacks: Theory and Evidence from the ERM since August 1993', Journal of International Economics, 49, 1-29.

Bertola, G., and R. Caballero (1990), 'Target Zones and Realignments', CEPR Discussion Paper No. 398, March.

Calvo, Guillermo (1996), 'Capital Flows and Economic Management', Federal Reserve Bank of San Francisco Working Paper in Applied Economic Theory No. 96-02

Campa, José M., and P. H. Kevin Chang (1998), 'ERM Realignments Risk and Its Economic Determinants as Reflected in Cross-Rate Options', The Economic Journal, 108, July, 1046-66. 
Caramazza, Francesco, Luca Ricci and Ranil Salgado (2000), 'Trade and Financial Contagion in Currency Crises', IMF Working Paper No. 00/55, March.

Cassola, N. (1995), 'Indicadores de Credibilidade de um Regime Cambial: os casos do Escudo e da Peseta no Sistema Monetário Europeu', Bank of Portugal, Research Department, February.

Dolado, J. J., J. A. Ayuso and S. Sosvilla-Rivero (1992), 'Efficiency in the Peseta Forward Exchange Rate Market', CEPR Discussion Paper No. 627, February.

Eichengreen, Barry, and C. Wyplosz (1993), 'The Unstable EMS', INSEAD Working paper 93/38/EPS, Fontainebleau, France.

Eichengreen, Barry, A. Rose and C. Wyplosz (1997), 'Contagious Currency Crises', Scandinavian Economic Review, 98, 4.

Favero, Carlo A., and Francesco Giavazzi (2000), 'Looking for Contagion: Evidence From the ERM', CEPR Discussion Paper No. 2591, October.

Forbes, K., and R. Rigobon (1999), 'No Contagion, Only Interdependence: Measuring Stock Market Co-Movements', NBER Working Paper No. 7267.

Glick, Reuven, and Andrew Rose (1999), 'Contagion and Trade: Why are Currency Crises Regional?', Journal of International Money and Finance, 4(18), 603-17.

Goldstein, Morris, Graciela Kaminsky and Carmen Reinhart (2000), Assessing Financial Vulnerability: An Early Warning System for Emerging Markets. Washington: Institute for International Economics.

Gómez-Puig, Marta, and José G. Montalvo (1997), 'A New Indicator to Assess the Credibility of the EMS', European Economic Review, 41, 1511-35.

Isard, P. (1995), Exchange Rate Economics. Cambridge, UK: Cambridge University Press.

Jeanne, Olivier (1999), 'Currency Crises: A Perspective on Recent Theoretical Developments', CEPR Discussion Paper No. 2170, June.

Kaminsky, Graciela (1998), 'Currency and Banking Crises: The Early Warnings of Distress', Board of Governors of the Federal Reserve System, International Finance Discussion Paper No. 629, October.

Kempa, Bernd, and Michael Nelles (1999), 'Misalignments and Real Exchange Rates and the Credibility of Nominal Currency Bands', Weltwirtschaftliches Archiv, 135(4), 613-27.

Kodres, Laura, and Matthew Pritsker (1998), 'A Rational Expectation Model of Financial Contagion', Board of Governors of the Federal Reserve System, Finance and Economic Discussion Paper No. 1998-48, December.

Moutot, P., and D. Namur (1991), 'Taux de Change et Zone Cibles: Une Synthèse de la Littérature Récente', CRIEGE - URA CNRS 1420, Cahier de Recherche 91 204, Paris: Centre National de Recherche Scientifique. 
Peria, Maria Soledad Martinez (1999), 'A Regime Switching Approach to Studying Speculative Attacks: A Focus on Monetary System Crises', World Bank Policy Research Working Paper No. 2132, June.

Rose, A. K., and L. Svensson (1991), 'Expected and Predicted Realignments: The FF/DM Exchange Rate during the EMS', Institute for International Economic Studies Seminar Paper No. 485. Stockholm.

Sutherland, A. (1995), 'Currency Crisis Models: Bridging the Gap between Old and New Approaches', in C. Bordes, E. Girardin and J. Melitz (eds), European Currency Crises and After, Manchester: Manchester University Press, 57-81.

Svensson, L. (1990), 'The Term Structure of Interest Rates Differentials in a Target Zone: Theory and Swedish Data', NBER Working Paper No. 3374.

Svensson, L. (1991a), 'Assessing Target Zone Credibility: Mean Reversion and Devaluation Expectations in the EMS', CEPR Discussion Paper No. 580, September.

Svensson, L. (1991b), 'The Simplest Test of Target Zone Credibility', CEPR Discussion Paper No. 493, January.

Williamson, John (2000a), 'Capital Mobility, Contagion, and Crises', in M. Abreu and V. Mendes (eds) What Financial System for the Year 2000?, Lisboa: Bolsa de Valores de Lisboa e Porto, 219-27.

Williamson, John (2000b), Exchange Rate Regimes for Emerging Markets: Reviving the Intermediate Option. Washington: Institute for International Economics. 